\title{
A POLLENANALYTICAL INVESTIGATION OF A BORING MADE NEAR A RIVER DUNE IN SOUTH-HOLLAND
}

\author{
A. VOORRIPS \\ (Botanical Museum and Herbarium, Utrecht) \\ (received January 27th, 1964)
}

\begin{abstract}
In this investigation special attention was paid to phytosociological aspects. The period in which the layers were formed could be dated as extending from the beginning of the Atlanticum to the present day. Radio-carbon dating is necessary, however, in order to obtain more precise results. It is not excluded that transgressions have influenced the succession. More investigations are necessary to complete our image of the holocene development of this area.
\end{abstract}

\section{INTRODUCTION}

The post-glacial genesis of the western part of the Netherlands is comparatively well known at present. Publications like the theses by J. Bennema (1954) and by S. Jelgersma (1961) and like the treatise by Dr. L. J. Pons and Dr. A. J. Wrggers (1959), make it clear that the post-glacial genesis of the western part of the Netherlands is characterized by several, large as well as small, transgressions. However, it should be realized that the majority of the areas investigated by the above-mentioned authors, is situated north of the line The Hague-Utrecht, in many cases even north of Amsterdam. Moreover, in all these investigations but little attention was paid to palynology; though diagrams have been published, in most cases dating was done by the radio-carbon method, whilst the phytosociological aspects were almost entirely neglected.

From data obtained from the "Segtion for SoILmechanics of THE MUNICIPALITY OF RotTERDAM" it was learned that there is a sand hill at Hillegersberg, in the north-eastern part of Rotterdam. The area occupied by this hill is about 3 ha. The base lies about $12 \mathrm{~m}$ below N.A.P., the summit about $0.5 \mathrm{~m}$ above N.A.P. The hill sides are said to be covered by a peat layer with a thickness of about $8 \mathrm{~m}$, and directly resting on sand. It appeared from literature, that this hill is a river dune of pleistocene or early holocene age. In the southwestern part of the Netherlands circ. 40 of these river dunes are known, for the greater part situated in the Alblasserwaard and Krimpenerwaard.

From a publication by F. Florschütz and I. M. VAN DER Vlerk (1939) it was learned that below Rotterdam peat of boreal age is 
found. It seemed interesting to see whether the peat on the hill sides, which is said to rest directly on pleistocene sand, perhaps had been developing without interruptions since the Boreal. In that case the various transgressions might find their expression in vegetational changes.

For that reason a boring was made near the dune of Hillegersberg, at a place situated about $15 \mathrm{~m}$ to the east of the church which stands on the hill. The code of this boring is Hi. The upper $90 \mathrm{~cm}$ turned out to be badly disturbed; for that reason this part of the boring was discarded. Then a peat layer followed with a thickness of about $5 \mathrm{~m}$, then a clay layer of about $2 \mathrm{~m}$, which rested on sand. That the clay layer was identified by the "SECTION FOR SoIlmechanics" as peat, is probably due to the method they had been using. This method rests on the estimation of soil's resistance, and so a soft clay may be identified with peat. As the clay layer proved to contain a fairly large amount of pollen, we decided to go on with the investigation, notwithstanding the wrong presupposition.

The questions to which we tried to find an answer may be formulated as follows:

a. What is the history of the dune vegetation?

$b$. What is the history of the vegetation in the immediate vicinity?

c. Are transgressions noticeable in the history of these vegetations?

However, it will be clear that these points have so much in common, that it is difficult to keep them apart.

\section{Material and Methods}

Field work

The samples were collected by means of a Dachnowsky sonde in the modification developed at Utrecht (EsHurs, 1946). The cylinders of soil which were obtained in this way, were preserved in glass test tubes. This method of preserving the samples has the advantage that the soil is neither desiccated nor transformed.

\section{Laboratory work}

Each cylinder was divided longitudinally into two halves. One half was used for the stratigraphic work, the other half for the palynological investigation.

a. The stratigraphic work. The stratigraphic work was carried out in order to obtain a better insight in the character of the vegetations which succeeded each other on the site of the boring itself. For this purpose a study was made of the macroscopically recognizable rests, including, for instance, fruits, leaves, wood, etc.

This work was carried out in three stages, viz.

$a$. by direct inspection of the soil samples; 
$b$. by making a suspension of the soil in water; in such a suspension seeds come to the surface and can be removed by means of a brush;

c. by sieving the soil suspension and investigating the residue.

b. The palynological investigation. From the halved cylinder a small sample was taken at the required depth. This sample was treated according to the method of FAEGRI and Iversen (1950). After the investigation the rest of the sample was stored in a small glass tube (for preservation some phenol was added).

Tree-pollen sum $(A P)$

The AP comprises the pollen grains of:

$\begin{array}{lll}\text { Alnus } & \text { Quercus } & \text { Fagus } \\ \text { Betula } & \text { Ulmus } & \text { Carpinus } \\ \text { Corylus } & \text { Tilia } & \\ \text { Salix } & \text { Fraxinus } & \\ \text { Pinus } & \text { Acer } & \\ \text { Picea } & & \\ \text { Abies } & & \end{array}$

In most cases up to $200 \mathrm{AP}$ was counted, in some cases up to $150 \mathrm{AP}$, and up to 50,75 or $100 \mathrm{AP}$ in a few other ones. The results of the last-mentioned countings have to be considered with some reserve. In samples with a large amount of pollen, up to 500 AP was counted.

The diagram (see Fig.)

The diagram has been divided into a number of subdiagrams, each with its own scale. The first diagram gives the curves obtained

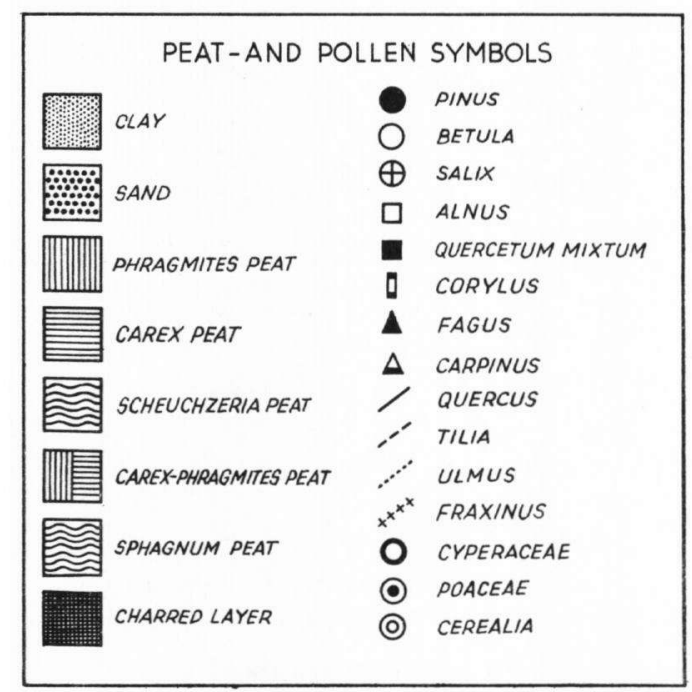


for Alnus, Betula, Salix, Pinus and the Quercetum mixtum (QM). The next three subdiagrams represent the different components of the $Q M$. The fifth subdiagram gives the curves for Fagus and Carpinus. The other subdiagrams have been divided in the following way:

a. a subdiagram comprising Poaceae non Cerealia, Cyperaceae, Cerealia;

b. a subdiagram comprising Dryopteris, Osmunda;

c. a subdiagram for Sphagnum;

d. a subdiagram for Calluna and Erica;

e. subdiagrams with typical aquatic plants;

$f$. in alphabetical order the other herbs, each with its own curve.

Of the herbs that have been found at best five times, no graphs are given, but they are recorded with name and percentage at the depth at which they were found. The same has been done with the wood fragments.

\section{Results}

The palynological results are rendered in the diagram. The stratigraphic results are succinctly mentioned in the column in front of the diagram. The exact composition, both lithological and botanical, is given in the next table.

\section{TABLE 1}

20- $40 \mathrm{~cm}$ : Clay with gravel and brick fragments.

$40-60 \mathrm{~cm}$ : Clay with gravel.

$60-80 \mathrm{~cm}$ : Clay with fine gravel.

Fruits: Juncus sp.

Rumex cf. acetosella.

80-100 cm: Somewhat coarse clay.

Fruits from Rumex cf. acetosella.

100-120 cm: Somewhat coarse clay.

Fruits: Rumex sp.

Carex sp.

Carex roots.

Ranunculus cf. fluitans.

120-140 cm: Peaty clay.

Fruits and seeds: Rumex sp. (acetosa or maritima)

cf. Chenopodium

cf. Trifolium

140-160 cm: Peaty clay.

cf. Fabaceae.

Fruits: cf. Rumex

cf. Trifolium.

160-180 cm: Rather fine peat.

Fruits: cf. Rumex

cf. Chenopodium

cf. Stellaria (1 ex.)

Rather many leaves and stems of Sphagnum sp.

180-200 cm: Rather coarse peat with some clay.

Fruit cf. Chenopodium.

Phragmites rhizomes and Carex roots. 
200-210 cm: Rather coarse peat with some clay.

Fruits: cf. Chenopodium Sonchus sp. (1 ex.)

Sphagnum leaves and Carex roots.

210-218 cm: Layer containing very small, black branches $(0,2-2 \mathrm{~cm})$.

218-245 cm: Somewhat clayey peat.

Fruits: cf. Chenopodium cf. Polygonaceae Funcus inflexus (1 ex.) Carex sp.

Phragmites epidermis, Carex roots and pieces of Sphagnum.

At $230 \mathrm{~cm}$ : Wood from Frangula ainus.

$245-320 \mathrm{~cm}$ : Rather loose, slightly fibrous peat.

Carex roots and Phragmites rests.

At $270 \mathrm{~cm}$ : Wood from Frangula alnus.

At $310-320 \mathrm{~cm}$ : Wood from Betula cf. verrucosa.

320-360 cm: Very loose, fibrous peat.

Fruits: Funcus cf. squarosus.

Very many Carex roots.

Rather many leaves from Sphagnum cf. imbricatum.

At $330 \mathrm{~cm}$ : Wood from Salix sp.

At 340-360 cm: Wood from Frangula alnus.

$360-400 \mathrm{~cm}$ : Coarse, very fibrous peat.

Carex- and Scheuchzeria rests.

$400-420 \mathrm{~cm}$ : Very loose, fibrous peat.

Very many Carex roots.

At $410 \mathrm{~cm}$ : Wood from Salix sp. and Quercus sp.

$420-440 \mathrm{~cm}$ : Loose peat with coarse fibres.

Carex roots and Phragmites rests.

At $430 \mathrm{~cm}$ : Wood from Salix sp.

$440-460 \mathrm{~cm}$ : Rather solid peat, very fibrous.

Fruits: Chenopodiaceae

Polygonum cf. hydropiper (1 ex.)

Carex sp.

Carex roots and Phragmites rests.

460-480 cm: Rather coarse, rather fibrous peat.

Many Carex- and Phragmites rests.

480-500 cm: Rather solid, fibrous peat.

Fruits: Scirpus sp.

Carex sp.

Many Carex roots and Phragmites rests.

500-520 cm: Rather loose, fibrous peat.

Fruits: Carex $s p$.

Carex roots and Phragmites rests.

520-560 cm: Somewhat clayey peat, with coarse fibres.

Carex roots and Phragmites rests.

At $540 \mathrm{~cm}$ : Wood from Quercus of. petraea.

$560-580 \mathrm{~cm}$ : Solid fine peat, clayey, not fibrous.

Fruits: cf. Polygonaceae

$$
\text { Chenopodium } s p \text {. }
$$

Carex roots and many Phragmites rests.

$580-615 \mathrm{~cm}$ : Clayey peat with rather coarse fibres.

Fruits: Polygonum sp.

Carex sp.

Carex roots and Phragmites rests.

615-630 cm: Somewhat peaty clay.

Carex roots and Phragmites rests.

630-795 cm: Fine, gray clay, sandy at the bottom. At $630 \mathrm{~cm}$ : Wood from cf. Quercus.

$795-810 \mathrm{~cm}$ : Rather coarse to coarse sand. 


\section{Discussion}

In considering the Hi-profile, it should be realized that the pollen was derived from various sources. It should be borne in mind that the boring was made against the side of a hill. So in the diagram firstly the vegetation on the hill will play its part, the hill vegetation; secondly the vegetation at the place of the boring itself, the hill side vegetation; and thirdly the vegetation in the surrounding area, the surrounding vegetation.

By the aid of borings, made by the "Section for SoILmechanics" a profile could be composed (see fig. 1).

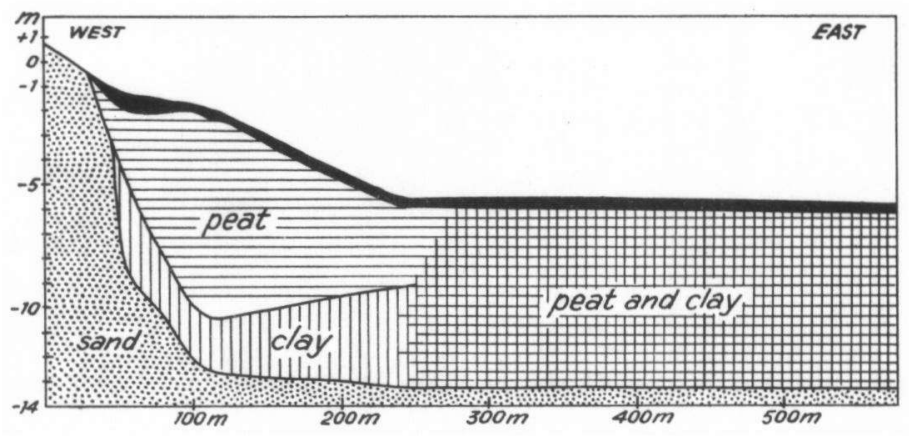

The composition and succession of the layers leads to the following suppositions:

a. When the hill is regarded as a river dune, it did fly up in the Late glacial, from a late glacial river valley.

$b$. After the riverdune was formed, (a) meandering river(s) deposited clayey river-basin soils.

c. The meandering river became a tidal river. Between the different river branches, peat developed. Far from the river branches this peat is oligotrophic. The alteration from a meandering river into a tidal river may in this case be due to a transgression of the sea.

As the meandering as well as the tidal river from time to time changed their course, borings made in the surrounding area show a tangle of clay and peat layers.

From $810-630 \mathrm{~cm}$ the Hi-profile changes from sand into fine gray clay without macroscopical rests. This agrees with the composition of clayey river-basin soils. At $630 \mathrm{~cm}$ wood fragments were found together with the first Carex- and Phragmites rests; Carex-Phragmites peat starts at about $615 \mathrm{~cm}$. It appears from the diagram that from $800-630 \mathrm{~cm}$ Sparganium is well represented, but that it declines towards $630 \mathrm{~cm}$. Lemna is present from 800-740 cm, Poaceae and Cyperaceae are continually present.

The first stages of a transformation from water into land are visible here. First there is an open water with Lemna and Sparganium (or 
Typha angustifolia), later on with Carex and Phragmites; with the latter two at last starts the development of peat.

The vegetation in the surrounding area probably showed much resemblance with the "Biesbos" (a virgin part of North Brabant exposed to the influence of the tides in the North Sea, i.e. the mineral soils (like river levees) bore an Alnion incanae, Ulmion or Salicion, the more peaty parts an Irido-Alnion; or vegetations developing into these associations.

In the diagram the Pinus-Alnus crossing at once attracts attention. It is found at $780 \mathrm{~cm}$ and can be dated as at the beginning of the Atlanticum. The percentages of the $Q M$ do not change much from $800-650 \mathrm{~cm}$, whilst after that a rise is noted which reaches its maximum at $590 \mathrm{~cm}$. The Pinus curve falls regularly; above $570 \mathrm{~cm}$ it stays below $5 \%$. Corylus on the contrary rises, with a maximum at $650 \mathrm{~cm}$, and than falls quickly. Betula and Salix are present in small percentages, just like Tilia, whilst Ulmus shows at circ. $550 \mathrm{~cm}$ a decrease. Quercus is responsible for the greater part of the $Q M$ curve, among other things for the rise at $650 \mathrm{~cm}$. Fraxinus is present from $800-715 \mathrm{~cm}$.

The decrease of Ulmus may coincide with the end of the Atlanticum, as is assumed here, but a radio-carbon dating would be necessary to settle this point.

We may conclude that the hill was covered with forest. The oldest forest was an Ulmion, at first with some Pinus. When the Ulmion was completely developed, the soil began to deteriorate, and a Quercion roboris took its place. The deteriorisation may here be due to the development of peat round the hill, which in this way was deprived of the supply of eutrophic (ground) water from the surrounding area.

From $490-370 \mathrm{~cm}$ a continued impoverishment of the hill vegetation is visible. At $410 \mathrm{~cm} \mathrm{Calluna,} \mathrm{up} \mathrm{to} \mathrm{there} \mathrm{but} \mathrm{poorly} \mathrm{represented,}$ suddenly reaches high percentages. Betula too rises strongly. The fact that the wood rests found at $310 \mathrm{~cm}$ were determined as Betula $c f$. verrucosa, makes it possible that the pollen too is from Betula verrucosa.

Now it can be said, that the vegetation changed from a VioletoQuercion into a Vaccinio-Quercion. More grounds for this supposition are found in the disappearance of Caryophyllaceae, Rubiaceae and Apiaceae at the moment that Calluna began to rise. For this impoverishment, as stated above, the peat layers round the hill are supposed to be responsible.

On the hill side itself a succession is visible too. From $615-510 \mathrm{~cm}$ there is clay in the peat, but upwards the amount continually decreases. A fall of Quercus and a come-back of Ulmus and Fraxinus are noted at $510 \mathrm{~cm}$ whilst Alnus and Corylus simultaneously rise. From 610$510 \mathrm{~cm}$ high Dryopteris percentages are present. The next stages in a succession look as follows.

First Carex-Phragmites peat, later on with much Dryopteris thelypteris, after that an Alnion glutinosae, perhaps an Alnion incanae $(510-410 \mathrm{~cm})$. 
The same can be said of the surrounding area, on the understanding that on the mineral soils (like river levees) an Ulmion will have been present.

Transgressions do not show clearly in this diagram. An indication for a transgression is perhaps to be seen in the rise of Chenopodiaceae from $490-445 \mathrm{~cm}$. The appearance of Sparganium and Lemna in these spectra might be another indication, but more investigations are necessary here to prove the influence of a transgression.

From $410 \mathrm{~cm}$ the peat at the hill side itself begins to become more oligotrophic. From $400-360 \mathrm{~cm}$ Scheuchzeria rests are present, from $360 \mathrm{~cm}$ Sphagnum rests. In the diagram Sphagnum gets a continuous curve from $325 \mathrm{~cm}$.

Curious are the rather high percentages of Osmunda in the spectra from 325-275 cm. Is this connected with the rise of Quercus in this zone? Has it something to do with the first settlement of men? It is difficult and at any rate at this stagé of our knowledge still impossible to explain.

At $330 \mathrm{~cm}$ Fagus appears. At $305 \mathrm{~cm}$ Cerealia start, though with low percentages. At $275 \mathrm{~cm}$ Tilia disappears, whilst from $270 \mathrm{~cm}$ Quercus falls definitely. At $250 \mathrm{~cm}$ Cerealia show a distinct increase. Many herbs appear with at once rather high percentages. The Fagus curve becomes continuous and the Alnus percentages rise quickly to values over $60 \%$.

It is quite justified to put here the boundary line between Subboreal and Subatlanticum. The settlement of men has become a fact too.

From $250-90 \mathrm{~cm}$ nothing changes.

Pollen grains from Linum usitatissimum have been found from 240$220 \mathrm{~cm}$, i.e. at the time of the expansion of the Cerealia. This proves that men brought the flax too with them. HeGi (1925) says that about the beginning of our era Linum usitatissimum began to supersede the other Linum species used by men and became established throughout Europe. In this way the settlement of men in the western part of the Netherlands must be dated about or after that time.

\section{Conclusions}

a. The Hi-profile can be dated as extending from the beginning of the Atlanticum to the present day.

b. However, radio-carbon dating will be necessary.

c. Transgressions may have influenced the successions, but this could not be proved.

d. More investigations of this hill and of other river dunes are necessary. 


\section{ACKNOWLEDGEMENTS}

The investigation was carried out at the Botanical Museum and Herbarium, Utrecht (Director: Professor Dr. J. Lanjouw), in the year 1962.

The author expresses his indebtness to Professor Dr. F. P. Jonker for his guidance and his never failing interest. He also wishes to thank Dr. C. R. JANSSEN and Dr. W. Punr, for their valuable support and their many advices, and Mr. Tr. SCHIPPER for the drawings.

\section{REFERENGES}

Bennema, J. 1954. Bodem- en zeespiegelbewegingen in het nederlandse kustgebied. Wageningen.

and L. J. Pons. 1952. Donken, fluviatiel laagterras en eemzee-afzettingen in het westelijk gebied van de grote rivieren. Boor en Spade 5: 126.

DonselaAR, J. Van. a.o. 1961. On the vegetation of former riverbeds in the Netherlands. Wentia 5: 1.

Edelman, G. H. 1950. Soils of the Netherlands. Amsterdam.

EshuIs, H. J. 1946. Palynologisch en stratigrafisch onderzoek van de Peelvenen. Med. Bot. Mus. Utrecht 94: 36 .

Faber, F. J. 1960. Aanvullende hoofdstukken over de Geologie van Nederland. Gorinchem. 4: 438.

FaGRI, K. and J. Iversen. 1950. Textbook of modern Pollen analysis. Copenhagen.

Florschütz, F. en I. M. VAN DER VLERK. 1939. Duizend eeuwen geschiedenis van den bodem van Rotterdam. De Maastunnel 2-6: 1 .

Hegi, G. 1925. Ill. Flora von Mittel-Europa 5-1: 20.

JANSSEN, C. R. 1960. On the late-glacial and post-glacial vegetation of South Limburg. Amsterdam.

Jelgersma, S. 1961. Holocene sea level changes in the Netherlands. Maastricht. Jong, J. D. DE. 1962. Geologie en Hydrologie van het Deltagebied. Nat. Voordr. nieuwe reeks 40: 155 .

Jonker, F. P. 1950. Botanische bijdrage tot het onderzoek van holocene transgressie en regressie. Ned. Kruidk. Arch. 57: 31 .

1950. Het botanisch onderzoek naar het optreden van transgressies en regressies. Ned. Kruidk. Arch. 57: 123.

Leeuwen, Chr. G. van en H. Doing Kraft. 1959. Landschap en beplanting in Nederland. Wageningen.

Pannexoex, A. J. a.o. 1956. Geologische geschiedenis van Nederland. 's-Gravenhage.

Pons, L. J. en A. J. Wiggers. 1959-1960. De holocene wordingsgeschiedenis van Noordholland en het Zuiderzeegebied. Tijdschr. Kon. Ned. Aardr. Gen. 76-2: 104 en 77-1: 3.

VINK, T. 1926. De Lekstreek. Een aardrijkskundige verkenning van een bewoond deltagebied. Amsterdam. 